\title{
Partial melting of metavolcanics in amphibolite facies regional metamorphism
}

\author{
Alan Bruce Thompson \\ Department of Earth Sciences, ETH Zürich, CH-8092, Switzerland. \\ e-mail: alan.thompson@erdw.ethz.ch
}

\begin{abstract}
Metavolcanic rocks containing low-Ca amphiboles (gedrite, cummingtonite) and biotite can undergo substantial dehydration-melting. This is likely to be most prominent in Barrovian Facies Series (kyanite-sillimanite) and occurs at the same time as widespread metapelite dehydrationmelting. In lower pressure facies series, metavolcanics will be represented by granulites rich in orthopyroxene when dehydration occurs at much lower temperatures than melting. In higher pressure facies series it is not well known whether metavolcanic rocks dehydrate or melt at temperatures lower or similar to that of metapelites.
\end{abstract}

\section{Introduction}

Basaltic and other metavolcanic rocks are often interlayered with metasediments in regional metamorphic terrains. At the "second-sillimanite" dehydration isograd (e.g. Evans and Guidotti 1966) represented by the reaction (figure 1)

$$
\mathrm{Mus}+\mathrm{Alb}+\mathrm{Qtz}=\mathrm{Ksp}+\mathrm{Sil}+\mathrm{H}_{2} \mathrm{O}
$$

(ca. $700^{\circ} \mathrm{C}$ at $\mathrm{P}$ ca 5 kbar; Tracy et al 1976 ; Thompson and Tracy 1979), metapelites often show signs of partial melting through the reaction

$$
\mathrm{Mus}+\mathrm{Alb}+\mathrm{Qtz}=\mathrm{Ksp}+\mathrm{Sil}+\mathrm{L}
$$

(figure 1)-while amphibolites remain unmelted except where they have been flushed with $\mathrm{H}_{2} \mathrm{O}$ (e.g. Percival 1983; Pattison 1991; Mogk 1992). Metapelite melting can occur by dehydration (fluid-absent) melting of muscovite at about $700^{\circ} \mathrm{C}$ (at ca. $5 \mathrm{kbar}$, figure 1) followed by biotite at about $750^{\circ} \mathrm{C}$, whereas dehydration-melting of hornblende in amphibolites appears to require temperatures near $900^{\circ} \mathrm{C}$ (e.g. Wolf and Wyllie 1991; Rushmer 1991; Rapp et al 1991; Beard and Lofgren 1991; Wyllie and Wolf 1993). $\mathrm{H}_{2} \mathrm{O}$-saturated melting of pelite occurs at relatively low temperatures of about $620^{\circ} \mathrm{C}$ at $10 \mathrm{kbar} . \mathrm{H}_{2} \mathrm{O}$-saturated melting of tonalite and basalt occurs at temperatures just above this (figure 1).

\section{Partial melting of amphibolite-facies cummingtonite and biotite-bearing metavolcanics compared to metapelitic compositions}

In parts of the metamorphic high of Central Massachusetts and SW New Hampshire USA, careful studies have been made of the metamorphism of basaltic and other metavolcanics (e.g. Robinson and Jaffe 1969; Robinson et al 1982; Spear 1977, 1982). The metamorphism of these rocks has been closely matched to the six zones (I-VI) of metamorphism of metapelites (see Tracy et al 1976; Tracy 1978, 1985). In zones IV to VI, metavolcanics of mafic and intermediate composition show signs of partial melting (Hollocher 1985, 1991; Schumacher et al 1990). Anastomising veins, small dykes and pods of coarse grained tonalitic rocks in amphibolite are reported from zones V and VI.

Robinson et al (1986, p. 235) noted that the partial melts form a few per cent of mafic rocks in zones IV and $\mathrm{V}$, but make up to $15 \%$ in

Keywords. Metavolcanics; gedrite; cummingtonite; biotite; dehydration-melting; granulites; orthopyroxene; experimental studies; amphibolite; Metapelite. 


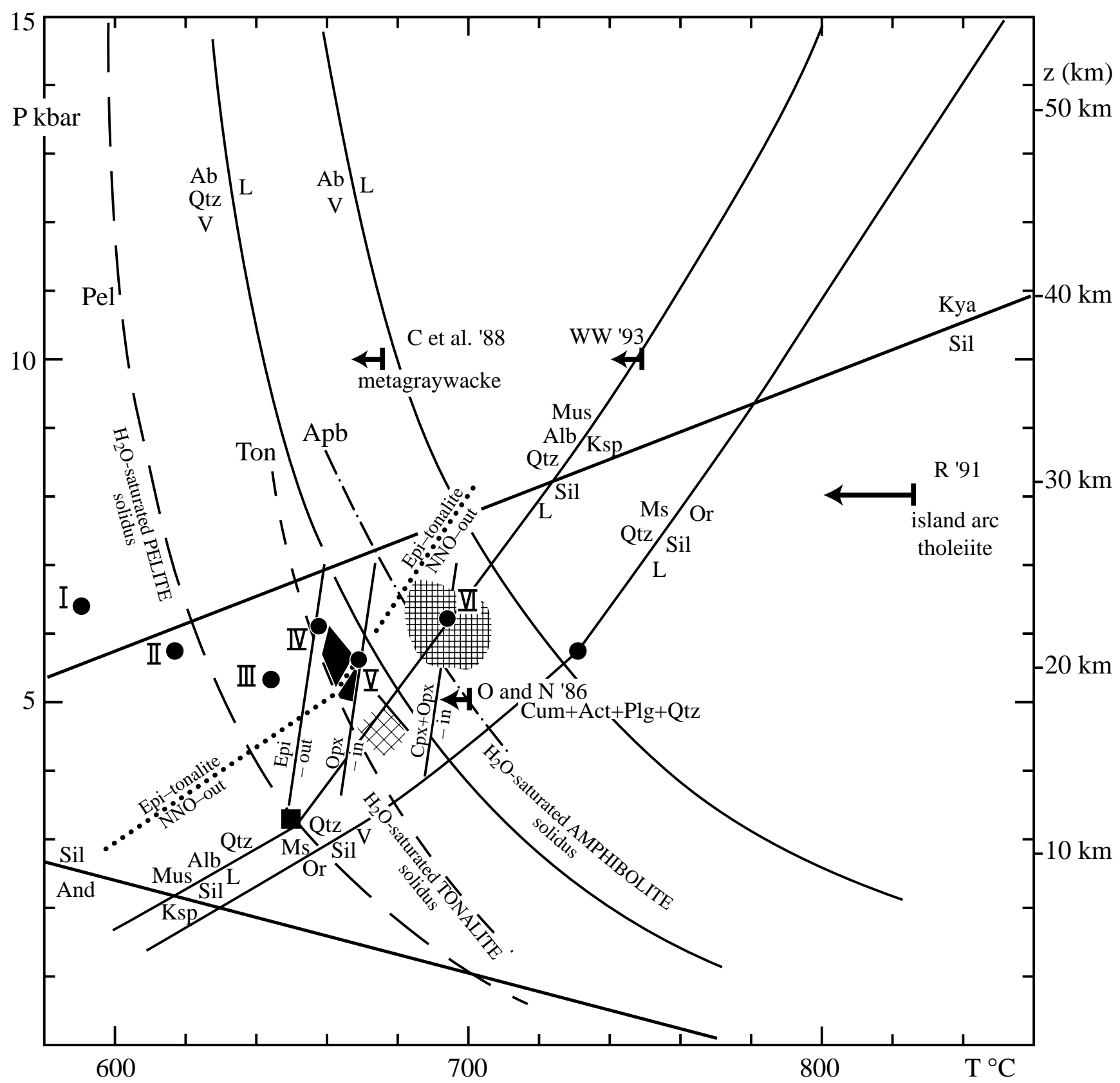

Figure 1. Some experimental and regional metamorphic constraints for beginning of partial melting in metavolcanics. Experimental constraints:

$\mathrm{Ab}\left(\mathrm{NaAlSi}_{3} \mathrm{O}_{8}\right)+\mathrm{Qtz}\left(\mathrm{SiO}_{2}\right)+\mathrm{V}\left(\mathrm{H}_{2} \mathrm{O}\right)=\mathrm{L}$ and $\mathrm{Ab}\left(\mathrm{NaAlSi}_{3} \mathrm{O}_{8}\right)+\mathrm{V}\left(\mathrm{H}_{2} \mathrm{O}\right)=\mathrm{L}$ from Huang and Wyllie $(1975) ;$ $\mathrm{Al}_{2} \mathrm{SiO}_{5}$ (Kya-Sil, And-Sil from Holdaway 1971);

muscovite dehydration and melting for mica and feldspar in KNASH (Mus, Alb, Ksp) and in KASH (Ms, Or, from Thompson and Algor 1977 figure 8 p. 262, reactions 14 and 19, 3 and 4);

Pel $=\mathrm{H}_{2} \mathrm{O}$-saturated PELITE solidus (data summarised by Thompson 1982; Thompson and Connolly 1995).

Dotted line shows experimentally investigated upper temperature stability limit for epidote (Epi) in tonalite with excess $\mathrm{H}_{2} \mathrm{O}$, at $\mathrm{fO}_{2} \sim \mathrm{NNO}$ (Schmidt and Thompson 1996, figure 5, p. 471);

Ton $=\mathrm{H}_{2} \mathrm{O}$-saturated TONALITE solidus (Wyllie 1977; Schmidt and Thompson 1996); Apb = $\mathrm{H}_{2} \mathrm{O}-$ saturated AMPHIBOLITE solidus (Wyllie 1977; Wolf and Wyllie 1991; Wyllie and Wolf 1993).

Arrows show where partial melting studies found melt at the indicated temperatures:-

$675^{\circ} \mathrm{C}, 10 \mathrm{kbar}$ - metagreywacke with $\mathrm{H}_{2} \mathrm{O}-\mathrm{CO}_{2}$ fluid $(\mathrm{C}$ et al ' $88=$ Conrad et al 1988);

$750^{\circ} \mathrm{C}, 10 \mathrm{kbar}$ - amphibolite dehydration melting (WW'93 = Wyllie and Wolf 1993);

$825^{\circ} \mathrm{C}, 8 \mathrm{kbar}$ - island arc tholeiitic dehydration melting with cummingtonite, biotite, hornblende ( $\mathrm{R}$ ' $91=\mathrm{Rushmer}$ 1991); 
zone VI. They contain about $40 \%$ coarse grained quartz with rutile needle inclusions, about $35 \%$ dark gray plagioclase $\left(\mathrm{An}_{20}-\mathrm{An}_{45}\right)$ containing oriented opaque oxide exsolution lamellae and about $15 \%$ mafic minerals, that include biotite (Bio), cummingtonite ( $\mathrm{Cum})$, hornblende $(\mathrm{Hbl})$, gedrite (Ged), garnet (Gar), magnetite (Mag), ilmenite (Ilm), orthopyroxene (Opx) and clinopyroxene (Cpx). Low-Ca amphiboles are more commonly known from several types of volcanics (e.g., Wood and Carmichael 1973; Wones and Gilbert 1982).

The melting reactions, in zones IV and V of the metamorphic high of Central Massachusetts, were interpreted as being dehydration-melting (fluidabsent) reactions by Robinson et al (1986, p. 251) and Schumacher et al (1990, p. 228)

$$
\begin{aligned}
& \mathrm{Cum}+\mathrm{Bio}+\mathrm{Plg}+\mathrm{Qtz}=\mathrm{Hbl}+\mathrm{Gar}+\mathrm{L}, \text { or } \\
& \mathrm{Cum}+\mathrm{Plg}=\mathrm{Hbl}+\mathrm{Opx}+\mathrm{L}, \text { and } \\
& \mathrm{Hbl}+\mathrm{Qtz}=\mathrm{Opx}+\mathrm{Cpx}+\mathrm{Plg}+\text { melt. }
\end{aligned}
$$

More recently Schumacher et al (1990, p. 227) have reinterpreted the partial melting to represent $\mathrm{H}_{2} \mathrm{O}$-present melting - because the $\mathrm{P}$ and $\mathrm{T}$ conditions obtained by geothermobarometry coincide with Wyllie's (1977) location of the $\mathrm{H}_{2} \mathrm{O}$-saturated solidus for tonalite (figure 1). Schumacher et al (1990, p. 226) locate invariant points in Fe and Mg end member systems on the basis of the intersection of the $\mathrm{H}_{2} \mathrm{O}$-saturated solidus reactions

$$
\begin{aligned}
\mathrm{Cum} & +\mathrm{Plg}+/-\mathrm{Qtz}+\mathrm{H}_{2} \mathrm{O}=\mathrm{Hbl}+\text { garnet } \\
& + \text { melt, and } \\
\mathrm{Cum}+\mathrm{Plg}+/-\mathrm{Qtz}+\mathrm{H}_{2} \mathrm{O}=\mathrm{Hbl}+\mathrm{Opx} & + \text { melt },
\end{aligned}
$$

with the dehydration reaction

$$
\mathrm{Cum}+\mathrm{Hbl}+\mathrm{Gar}+\mathrm{Qtz}=\mathrm{Opx}+\mathrm{Plg}+\mathrm{H}_{2} \mathrm{O} \text {. }
$$

For calculated geobarometric pressure of 5 to $6 \mathrm{kbar}$ these reactions are deduced from mineral geothermometry to have occurred between 655 and $670^{\circ} \mathrm{C}$.

Epidote disappears at zone IV (Schumacher et al 1990, p. 221) and so is not involved in metavolcanic dehydration melting in Central Massachusetts (in contrast to epidote's involvement in melting at higher pressures, Schmidt and Thompson 1996). Staurolite and gedrite occur only in low-Ca, highAl mafic rocks in zones I and II. Staurolite is thus not involved in dehydration melting at pressures of $6 \mathrm{kbar}$ although it is involved in metapelite dehydration melting higher pressures (Koons and Thompson 1985; Thompson and Connolly 1995; Spear et al 1999).

\section{Experimental studies of partial melting of cummingtonite and biotite-bearing assemblages compared to amphibolites}

Amphibolites containing only hornblende with plagioclase + quartz melt close to $900^{\circ} \mathrm{C}$ in dehydration-melting studies from 5 to $10 \mathrm{kbar}$ (e.g. Wolf and Wyllie 1991; Rushmer 1991; Rapp et al 1991; Beard and Lofgren 1991; Wyllie and Wolf 1993). Many metavolcanic rocks contain low-Ca amphiboles and biotite, the dehydration melting of which could well occur at lower temperatures than that of hornblende in amphibolites.

Rushmer (1991) showed that dehydration of an "island arc tholeiite" (ibid, mode on p. 44) containing hornblende $(44 \mathrm{wt} \%)+$ plagioclase $(32 \mathrm{wt} \%)$ + quartz $(17 \mathrm{wt} \%)$ with cummingtonite $(5 \mathrm{wt} \%)$, biotite (1wt\%), ilmenite $(1 \mathrm{wt} \%)$ and zoisite $(<$ $1 \mathrm{wt} \%$ ), contained 10 vol $\%$ glass at $825^{\circ} \mathrm{C}, 8 \mathrm{kbar}$, with Opx, Cpx, Qtz and residual hornblende (figure 1). Oba and Nicholls (1986) studied synthetic cummingtonite $(\mathrm{Mg}, \mathrm{Fe})_{7} \mathrm{Si}_{8} \mathrm{O}_{22}(\mathrm{OH})_{2}$ and actinolite $\mathrm{Ca}_{2}(\mathrm{Mg}, \mathrm{Fe})_{5} \mathrm{Si}_{8} \mathrm{O}_{22}(\mathrm{OH})_{2}$, for both of which $\mathrm{Mg} /(\mathrm{Mg}+\mathrm{Fe})=0.5$, reacting with $\mathrm{An}_{0}, \mathrm{An}_{20}, \mathrm{An}_{40}$ plus quartz, and excess of $\mathrm{H}_{2} \mathrm{O}$ at $5 \mathrm{kbar}\left(\mathrm{fO}_{2}\right.$ at $\mathrm{QFM})$. They reported glass at the lowest temperature of their runs $\left(700^{\circ} \mathrm{C}\right)$ for all compositions studied (figure 1). Conrad et al (1988, p. 774) reported clinoamphibole + orthoamphibole + biotite + plagioclase + quartz in experiments on a greywacke composition at $675^{\circ} \mathrm{C}$ at $\mathrm{PH}_{2} \mathrm{O}=$ $10 \mathrm{kbar}$, for $\mathrm{X}_{\mathrm{H}_{2} \mathrm{O}}^{\mathrm{va}}=1.0,0.75$ (figure 1). Kenah and Hollister (1983, p. 158) deduced temperature conditions close to $700^{\circ} \mathrm{C}, \mathrm{P}=3-7 \mathrm{kbar}$ for anatexis in the Central Gneiss complex in British Columbia. They also identified melting reactions involving biotite, hornblende and cummingtonite (ibid, p. 149).

\section{Figure 1 caption. (Continued)}

$700^{\circ} \mathrm{C}, 5 \mathrm{kbar}$ - cummingtonite + actinolite + plagioclase + quartz with excess $\mathrm{H}_{2} \mathrm{O}(\mathrm{O}$ and $\mathrm{N}$ '86 = Oba and Nicholls 1986).

The labels I to VI indicate the P-T conditions for the six regional metamorphic zones of Central Massachusetts, U.S.A. (Tracy et al 1976; Tracy 1978; Hollocher 1985, 1991; Robinson et al 1986; Schumacher et al 1990). The deduced limits for Epi-out (point IV), Opx-in (point V), and Opx + Cpx-in (point VI) are from observations summarised by Schumacher et al (1990, figures 9.14 and 9.18) — the illustrated reaction slopes for which may well be drawn too steeply and possibly the appropriate reactions should have $\mathrm{dP} / \mathrm{dT}$ slopes like the metapelite dehydration-melting reactions. 


\section{Partial melting of metavolcanics in relation to metamorphic facies series}

The metamorphic high of Central Massachusetts and SW New Hampshire, USA, is part of a Kyanite-Sillimanite Barrovian Facies Series. This particular pressure range for metamorphic $P-T-t$ paths encounters substantial overlap between dehydration reactions and $\mathrm{H}_{2} \mathrm{O}$-saturated solidi (figure 1). This means that dehydration-melting occurs very close in temperature to $\mathrm{H}_{2} \mathrm{O}$-saturated melting. It is most likely that some local $\mathrm{H}_{2} \mathrm{O}$ recycling occurred between the different partially melted rock types (e.g. Thompson 2001a, 2001b). Partial melting of metavolcanics may be widespread but is most commonly to be expected in Barrovian Facies Series. Lower pressure Facies Series (Andalusite-Sillimanite) exhibit dehydration at much lower temperatures than even $\mathrm{H}_{2} \mathrm{O}$ saturated melting, and the metavolcanics would appear as granulites without showing evidence for melt depletion. Higher pressure Facies Series (e.g. medium to high pressure amphibolites, or even blueschist to eclogite, show much higher temperatures for dehydration-melting than the $\mathrm{H}_{2} \mathrm{O}$-saturated solidi and would exhibit persistence of amphibolite rather than granulite to much higher temperatures (Thompson 1998a, 1998b).

\section{Conclusions}

The Barrovian Facies Series whose P-T-t paths pass through the 4 to $6 \mathrm{kbar}$ range $(15$ to $20 \mathrm{~km}$ depth for lithostatic pressure gradients, $\mathrm{P}=$ $1 \times \rho_{\text {rock }}$ gh) would exhibit the highest degrees of partial melting of metavolcanics, in addition to metapelites and metapsammites (Thompson 1988, 1990). More detailed studies of such medium pressure metamorphic terrains are desirable as they would be expected to show overlap of dehydrationmelting with $\mathrm{H}_{2} \mathrm{O}$-saturated melting, and be most likely to be the chemical source regions for midcrustal granites.

\section{Acknowledgements}

It is a great pleasure to contribute to this special issue honouring Prof. S K Sen for his substantial contributions to the investigation of high-grade rocks in India and elsewhere. It is also a pleasure to acknowledge many interesting hours of discussion in the laboratory and the field in Central Massachusetts with Bob Tracy, Peter Robinson, Kurt Hollocher and John Schumacher. I also thank J. S. Daly for reviewing, S. Bhattacharya for editing, Peter Nievergelt for drawing the figure, and the
ETH and Swiss National Science Foundation for support.

\section{References}

Beard J S and Lofgren G E 1991 Dehydration melting and water-saturated melting of basaltic and andesitic greenstones and amphibolites at 1, 3, and 6.9 kbar; J. Petrology 32 3665-401

Conrad W K, Nichols I A and Wall V J 1988 Water saturated and undersaturated melting of metaluminous and peraluminous crustal compositions at $10 \mathrm{kbar}$ : evidence for the origin of silicic magmas in the Taupo Volcanic Zone, New Zealand and other occurrences; J. Petrology 29 765-803

Evans B W and Guidotti C V 1966 The sillimanite-potash feldspar isograd in western Maine, U.S.A.; Contr. Mineral. Petrol. 12 25-62

Holdaway M J 1971 Stability of andalusite and the aluminum silicate phase diagram; Am. J. Sci.; 271, 97-131

Hollocher K 1985 Geochemistry of metamorphosed volcanic rocks in the Middle Ordovician Partridge Formation, and amphibole dehydration reactions in the high-grade metamorphic zones of Central Massachusetts; Ph. D Thesis, Contribution \# 56 (Department of Geology and Geography, University of Massachusetts, Amherst), pp 275

Hollocher K 1991 Prograde amphibole dehydration reactions during high grade regional metamorphism, Central Massachusetts, U.S.A.; Am. Mineral. 76 956-970

Huang W L and Wyllie P J 1975 Melting reactions in the system $\mathrm{NaAlSi}_{3} \mathrm{O}_{8}-\mathrm{KAlSi}_{3} \mathrm{O}_{8}-\mathrm{SiO}_{2}$ to 35 kilobars, dry and with excess water; J. Geology 83 737-748

Kenah C and Hollister L S 1983 Anatexis in the Central Gneiss Complex, British Columbia; Migmatites, Melting and Metamorphism (eds.) M P Atherton and C D Gribble (Proceedings of the Geochemical Group of the Mineralogical Society, London, Shiva Geology Series), pp $142-162$

Koons PO and Thompson A B 1985 Non-mafic rocks in the blueschist and eclogite facies; Chem. Geol., 50 3-30

Mogk D W 1992 Ductile shearing and migmatization at mid-crustal levels in an Archaean high-grade gneiss belt, northern Gallatin Range, Montana, USA.; J. Metamorph. Geol. 10 427-438

Oba T and Nicholls I A 1986 Experimental study of cummingtonite and $\mathrm{Ca}-\mathrm{Na}$ amphibole relations in the system Cum-Act-Pl-Qz- $\mathrm{H}_{2} \mathrm{O} ;$ Am. Mineral. 71 1354-1365

Pattison D R M 1991 Infiltration-driven dehydration and anatexis in granuilte facies metagabbro, Grenville Province, Ontario, Canada; J. Metamorphic Geol., 9 315-332

Percival J A 1983 High-grade metamorphism in the Chapleau-Foleyet Area, Ontario; Am. Mineral. 68 667-686

Rapp R, Watson E B and Miller C F 1991 Partial melting of amphibolite/eclogite and the origin of Archean trondhjemites and tonalites; Precambrian Research 51 1-25

Robinson P and Jaffe H W 1969 Chemographic exploration of amphibole assemblages from central Massachusetts and southwestern New Hampshire; Mineral. Soc. Am. Special Pap. 2 251-274

Robinson P, Spear F S, Schumacher J C, Laird J, Klein C, Evans B W and Doolan B L 1982 Phase relations of metamorphic amphiboles: Natural occurrence and theory; Mineral. Soc. Am. Revs. Mineral. 9B 1-211 
Robinson P, Tracy R J, Hollocher K T, Schumacher J C and Berry IV H N 1986 The central Massachusetts metamorphic high; Regional metamorphism and metamorphic phase relations in northwestern and central New England, Field Trip Guidebook (B-5), (eds.) P Robinson and D C Elbert (14th General Meeting, Internat. Mineral. Assoc. Standford, Ca. USA.), pp 195-284

Rushmer T 1991 Partial melting of two amphibolites: Contrasting results under fluid-absent conditions; Contrib. Mineral. Petrol. 107 41-59

Schmidt M W and Thompson A B 1996 Epidote in calcalkaline magmas: An experimental study of stability, phase relationships, and the role of epidote in magmatic evolution; Am. Mineral. 81 462-474

Schumacher J C, Hollocher K T, Robinson P and Tracy R J 1990 Progressive reactions and melting in the Acadian metamorphic high of central Massachusetts and southwestern New Hampshire, USA.; High-temperature metamorphism and crustal anatexis (eds.) J R Ashworth and M Brown (The Mineral. Soc. Series 2, Unwin Hyman Ltd. London) 198-234

Spear F S 1977 Phase equilibria of amphibolites from the Post Pond Volcanics, Vermont; Carnegie Inst. Washington Year Book 76 613-619

Spear F S 1982 Phase equilibria of amphibolites from the Post Pond Volcanics, Mt. Cube Quadrangle, Vermont; J. Petrology 23 383-426

Spear F S, Kohn M J and Cheney J T 1999 P-T paths from anatectic pelites; Contrib. Mineral. Petrol. 134 17-32

Thompson A B 1982 Dehydration melting of pelitic rocks and the generation of $\mathrm{H}_{2} \mathrm{O}$-undersaturated granitic liquids; Am. J. Sci. 282 1567-1595

Thompson A B 1988 Dehydration melting of crustal rocks; Rendiconti Soc. Italy Min. Pet. 43 41-60

Thompson A B 1990 Heat, fluids and melting in the granulites facies; Granulites and crustal evolution (eds.) D Vielzeuf and Ph Vidal (Nato ASI Series C. 311, Kluwer, Dordrecht). pp 37-57

Thompson A B 1998a Granulite facies processes and protoliths; The Dynamic Geosphere - Prof. W S Fyfe felicitation volume (ed.) A K Gupta (National Academy of Sciences, India), pp 1-12

Thompson A B 1998b A metamorphic norm for Granulite facies assemblages; The Dynamic Geosphere - Prof. WS Fyfe felicitation volume (ed.) A K Gupta (National Academy of Sciences, India), pp 13-20
Thompson A B 2001a Clockwise P-T paths for crustal melting and $\mathrm{H}_{2} \mathrm{O}$ recycling in granite source regions and migmatite terrains; Lithos $\mathbf{5 6} 33-45$

Thompson A B 2001b Internal versus external $\mathrm{H}_{2} \mathrm{O}$ sources, $\mathrm{H}_{2} \mathrm{O}$ recycling, and P-T paths for crustal melting; Phys. Chem. Earth 26 231-237

Thompson A B and Algor J R 1977 Model system for anatexis of pelitic rocks: I. Theory of melting reactions in the system $\mathrm{KAlO}_{2}-\mathrm{NaAlO}_{2}-\mathrm{Al}_{2} \mathrm{O}_{3}-\mathrm{SiO}_{2}-\mathrm{H}_{2} \mathrm{O}$; Contrib. Mineral. Petrol. 63 247-269

Thompson A B and Tracy R 1979 Model systems for anatexis of pelitic rocks: II. Facies series melting and reactions in the system $\mathrm{CaO}-\mathrm{KAlO}_{2}-\mathrm{NaAlO}_{2}-\mathrm{Al}_{2} \mathrm{O}_{3}-\mathrm{SiO}_{2}-$ $\mathrm{H}_{2} \mathrm{O}$; Contrib. Mineral. Petrol. 70 429-438

Thompson A B and Connolly J A D 1995 Melting of the continental crust: Some thermal and petrological constraints on anatexis in continental collision zones and other tectonic settings; J. Geophys. Res. 100 B8 15'565-579

Tracy R J 1978 High grade metamorphic reactions and partial melting in pelitic schist, West-Central Massachusetts; Am. J. Sci. 278 150-178

Tracy R J 1985 Migmatites occurrences in New England; Migmatites (ed) J R Ashworth (Blackie, Glasgow) 204224

Tracy R J, Robinson P and Thompson A B 1976 Garnet composition and zoning in the determination of temperature and pressure of metamorphism, Central Massachusetts; Am. Mineral. 58 762-775

Wolf M B and Wyllie P J 1991 Dehydration-melting of solid amphibolite at $10 \mathrm{kbar}$ : Textural development, liquid interconnectivity and applications to the segregation of magmas; Contrib. Mineral. Petrol. 44 151-179

Wones D R and Gilbert M C 1982 Amphiboles in the igneous environment; Mineral. Soc. Am. Reviews in Mineralogy 9B $355-390$

Wood B J and Carmichael I S E $1973 \mathrm{P}_{\text {total }}, \mathrm{P}_{\mathrm{H}_{2} \mathrm{O}}$ and the occurrence of cummingtonite in volcanic rocks; Contrib. Mineral. Petrol. 45 149-158

Wyllie P J 1977 Crustal Anatexis: An experimental review; Tectonophysics 43 41-71

Wyllie P J and Wolf M B 1993 Amphibolite dehydrationmelting: Sorting out the solidus; Magmatic Processes and Plate Tectonics (eds.) H M Prichard, T Alabaster, N B W Harris, C R Neary (Geol. Soc. London Special. Publication) $\mathbf{7 6} 405-416$ 